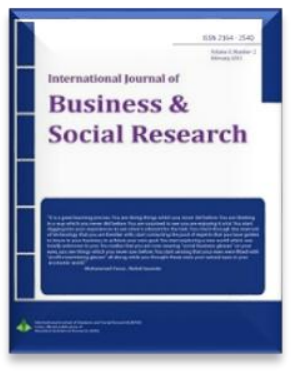

\title{
International Journal of Business and Social Research
}

Volume 07, Issue 08, 2017. 26-42

Article Received: 20-07-2017

Accepted: 19-08-2017

Available Online: 09-09-2017

ISSN 2164-2540 (Print), ISSN 2164-2559 (Online)

DOI: http://dx.doi.org/10.18533/ijbsr.v7i8.1060

\section{China-Pakistan Economic Corridor: In the context of 'String of Pearl Strategy}

\author{
Muhammad Salman Ahmad', Fahad Asmi², Madad Ali3 , Md. Mashiur Rahman4, \\ Syed Mudasser Abbas 5
}

\begin{abstract}
This paper narrates china's investment in South East Asian region and the up-gradation and construction of 'Deep Sea Ports' in countries such as Myanmar, Bangladesh, Sri Lanka and Pakistan. China's escalating growth of its naval bases and trade influences in Indian and South Chinese Ocean is globally coined as China's 'String of Pearls Strategy' (SOPs). Recently China has initiated \$46 Billion projects in Pakistan, connecting deep sea Port of Gwadar with Kashgar, which is mostly discussed in the literature as 'China-Pakistan Economic Corridor' (CPEC). This corridor is considered to be a game changer in South Asia's emerging economies. The current document is an approach of descriptive exploratory study to highlight the importance of String of Pearl theory in the strategic manner, the China's initiative of economic corridor and rapid re-structuring of the silk roads for the trade purpose. CPEC's investment in Pakistan and the political and power dynamics in the South East Asia among countries in terms of politics, internal situation and inter-country alliances. The current document highlighted and discussed the policies which Pakistan can be predicted to be followed to improve the effectiveness of CPEC.
\end{abstract}

Keywords: Chabahar, China-Pakistan Economic Corridor, International Relations, String of Pearls Strategy. JEL Codes: F15, O18, R12.

This is an open access article under Creative Commons Attribution 4.0 License, 2017.

\section{Introduction}

The phrase 'String of Pearls' describes the strategic long-term China's naval and trade influence in the Indian Ocean to strengthen the influence in the region. The String of Pearls Strategy' is driven by aggressive mediating policy to build diplomatic relations with the South Asian countries, i.e. Bangladesh,

\footnotetext{
${ }^{1}$ PhD Research Scholar, School of Public Affairs, University of Science and Technology of China, Hefei, Anhui, P.R. China, E-mail: sahmad@mail.ustc.edu.cn

2 PhD Research Scholar, School of Public Affairs, University of Science and Technology of China, Hefei, Anhui, P.R. China, E-mail: fasmie@mail.ustc.edu.cn

3 PhD Research Scholar, School of Public Affairs, University of Science and Technology of China, Hefei, Anhui, P.R. China, E-mail: ali12@mail.ustc.edu.cn

4 PhD Research Scholar, School of Public Affairs, University of Science and Technology of China, Hefei, Anhui, P.R. China, Email: mashiur@mail.ustc.edu.cn

5 Institute of Business Studies, Kohat University of Science and Technology, Kohat, Pakistan
} 
Pakistan, and Myanmar. It is observed that the diplomatic relations have led China with South Asian countries to develop and maintain the sea trade routes, such as Chittagong deep sea port Bangladesh and Pakistan (Yogesh, 2013).

In order to boost up regional collaboration and enhance mutual trust among neighbouring countries, the concept and implementation of an Economic Corridor (EC) is heading its way and considered as a top foreign policy strategies of Asia's sub-region to strengthen economic expansion and extend incorporation (wolf, 2016). In South Asia, fame of economic corridors is a further topical occurrence, at present the most superior example is that of the China-Pakistan Economic Corridor (CPEC) (Dent, 2016).

The visit in April 2015 by the Chinese president Xi Jinping's to Pakistan has been marked as one of the most exclusive and strategic economic deal regarding China's trade policy and its economic growth in the 21st century which is classified as the China-Pakistan Economic Corridor (CPEC) in media and literature (Ritzinger, 2015).The CPEC as a project was initially proposed in the year 2013 by the think tanks. In terms of economic value and project's scope, it is considered as a mega developmental project. It was proposed as one of the world's largest deep sea port to facilitate future needs (Jinchen, 2016). Specifically, it was targeted as a main outward off-shoring trading hub for China. Statistically, it will shorten china existing route to the Persian Gulf by more than 10,000 kilometres.

By using this trade route, it would take Chinese imports and exports only 10 days to reach its potential destination instead of 45 days-it will not only reduce the shipping cost, moreover, it will also avoid all the potentially challenges across the waterways near the Philippines, Taiwan, Vietnam, Indonesia \& India(Christ \& Ferrantino, 2011).

In the current scenario, it is estimated that more than 70\% of China's trade and power imports travel through the Indian Ocean, which is currently being watched and guard by the US and Indian law enforcement agencies. These potential security barriers are considered as the critical threat for China trade competencies. Specifically, the flow of trade commodities through this channel is comprised of Oil (40\%), and electronic goods and Minerals (30\%).

The essence of less agility in existing sea route through the Indian Ocean can produce the inconsistency in the country's energy supply. As a result, the trading supply would suffer to travel an additional 500 miles to avoid the risk. China is attentive to this susceptibility and is looking towards Pakistan to produce synergy to cope with the challenge and to develop an alternative route (Chowdhary, 2015).The CPEC has been a flag down by many analysts as a game changer which could help to incorporate and bond together the Central Asia, South Asia, and the Middle East economies. In addition, it will boost the Pakistan's laid up economy (Anholt, 2016).

So making a view in the context of system theory, it is important to understand the internal instability in terms of security, economy, and politics in Pakistan. In the meanwhile, the external response to this development is hard to determine, i.e. the strategic response of neighbouring countries like India and Iran.

\subsection{Purpose of this study}

The main purpose of this study is to explore the role of CPEC in the context of string of pearl strategy and also analyse its strength, opportunity and weaknesses which is under the flagship china's One Belt-One Road (OBOR) project. The foundation of this study is based on secondary source data i.e. Literature study, newspapers, magazines and credible websites.

\subsection{Problem statement}

Currently in south East Asia the China Pakistan Economic Corridor (CPEC) is under the lime light. China and Pakistan has a unique and unshakable relationship, both countries have cultural openness and systematic compatibility .A lot of study is going on china's One Belt-One Road (OBOR) project and its impact on neighbouring countries. However, very few research studies have been conducted on Pakistan's approach towards successful implementation of CPEC. This paper will highlight those issues and will suggest future oriented strategies and policies. 
1.3 Conceptually, the current study will have comprised of the following questions to be fulfilled

- Firstly, evaluating the role of CPEC in context of string of pearl strategy-how much it is important for china?

- Secondly, what's the meaning of "Economic Corridor"? What are the benefits, prospects of CPEC in context of One Belt-One Road (OBOR?)

- Thirdly, Comparison of Pakistan's port with Iran's Chahbahar port and also analysing India's concern regarding CPEC.

- Fourthly and most importantly exploring the policy designed by the Islamabad to achieve CPEC project, one has to consider its positive or negative impact on Pakistan's social, economic and political environment.

\section{Methodology}

For achieving the prime objectives, methodology defines the brief description of the philosophy, strategy, data collection and analysis method and the concerns of the ethical issues. In terms of the philosophy of the current piece of academic document, the interpretive view was adopted, as the theme is addressing the social and strategic situation which cannot be generalized in the law like format (Saunders, Lewis, \& Thornhill, 2009). While analyzing the situation and the stance of Pakistan as a country, the political, and economic and the security related factors are only reviewed. This classifies the current study as deductive in nature.

The CPEC as a situation in terms of country specific views has different combination of benefits and strategic worth, as the current document is addressing the challenging factors in the case of Pakistan. The current study can be labelled as 'Case study'. The data sources are mostly comprised of the credible media agencies, government documents, and the academic literature which have highlighted the geographic importance and the strategic value of CPEC. In other words, the most of the elements used as the data sources are narrative and qualitative in nature. However, the factual support in a quantified manner is also adopted which studying the case of Pakistan. The time horizon of the collected data is passive in nature. Specifically, the documents dated back to the year 2005 onwards are reviewed and considered as the possible sub-set for the current document. In terms of research methodology, the longitudinal time zone selected for the study. The methodological design is exploratory, as it is with the aim to increase the knowledge(Malhotra, \& Birks, 2007)and revealing affecting factors for CPEC in the view of Pakistan as a country. The data analysis in a quantified manner initially divided the collected data into broad categories and later further reduced to the concern dimensions, and in the final stage, it was interpreted in the fruitful output to support the proposed arguments and discussing the objectives of the current study. In other words, the conceptual guide by Robson was adopted where the authors of the current document adopted the stance of social scientists

In the ethical perspective, it is the responsibility and the prime value of the authors to express the situation in the unbiased manner(Robson, 2002). In the current document, the authors preferred to avoid the country-biases and strictly ignored the views in the existing literature which can affect the ethical values of the readers.

\section{Findings and analysis}

The following 4 sub-section will discuss each of the questions as discussed in the section 1.3 of the document

\subsection{The 'string of pearls' strategy}

In the year 2004, Booz Allen Hamilton (The United States' strategic analyst) published a research report with the title 'Energy Futures in Asia'. According to that report, the primary objective of China's investment in the coastal region between southern China and Pakistan's deep-sea port is to build a resilient network of naval bases. In the existing pool of knowledge, this philosophy of strategic network of naval bases is named as the 'String of Pearls Strategy' (Sops) (Marantidou, 2014). Every successful economy with the core competency of industrialization prefers to have a smart logistic 
infrastructure for consistent supply chain network. In the case of China, to deal with the existing security-related challenges in the supply routes, Chinese have taken keen entrust to construct and develop the key ports in South Asian countries. Beijing and Islamabad-In 2001, signs historical MoU to develop Pakistan's Deep Sea Port at Gwadar, which is situated in the Pakistan's less develop province (Baluchistan), according to that MoU Chinese Government will provide \$1.2 Billion for the development of the port (Niazi, 2005). To turn Gwadar port into major commercial and regional hub for trade and other activities, multi-purpose berths will be constructed. This project also involves connecting Xinjiang province in china with Gwadar through Railway line. This will create alternative supply route for Chinese trade (Shah, 2007-09).

In Bangladesh, the Chittagong deep-sea port has also been transformed and upgraded by China. The project includes linking of china's western part and landlocked western province of Yunnan through railway lines and roads. The overall project is estimated to be $\$ 8.7$ billion (Kurian, 2014).Lastly, Chinese state-owned company China National Petrochemical Corporation (CNPC) with Myanmar government has a joint venture to develop the port at Kunming a city of Myanmar and connect it with Yunnan through gas and oil pipelines. Regarding within the 'string of pearls' strategy context, there has been much debate of China's venture in ports in Myanmar(Pant, 2012). Subsequently, these seaports' locations along with vital checkpoints at Indian oceans, have given china opportunity to deepen the relationships with South Asian countries and also create space for china to establish naval bases at Indian oceans at strategic locations (Prasad, 2009). Each port at a different location has been alleged as 'pearl,' which in near future can be transformed into a naval base and serve as the military point for china at Indian Ocean (Kostecka, 2011). Due to the strategic mistrust between United States of America and India along with china.

The strategic analyst, mainly from US and India, observe these investments as china's effort to build its dominance and want to flex its muscles in the Indian Ocean. Because in the case of emergency or war like situation, china can use these ports to dispose of off any major rival before they took to manoeuvre. China's mushroom growth regarding its diplomatic ties with South Asian neighbours makes an uneasy environment for the Indian. India believes that china's such loop at the Indian Ocean can strangle India in its own backyard (Holmes, \& Yoshihara, 2008).

Figure 1: Graphical elaboration of 'String of Pearl Theory

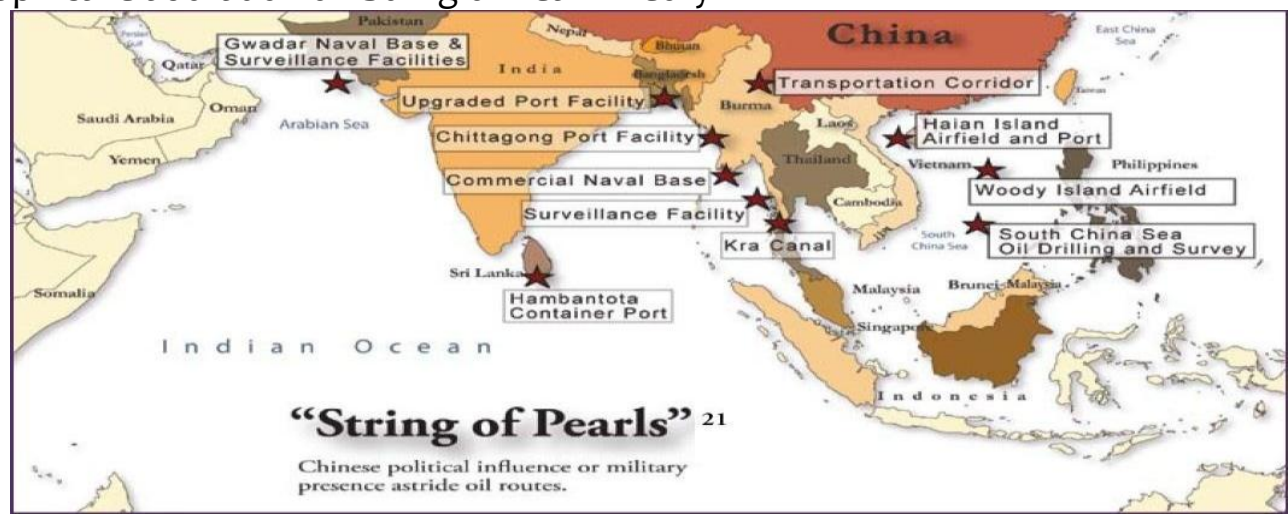

Until now three key distinctiveness comes out while examining china's strategic "pearls". First, while analysing these pearls, it gives us a basic idea and depicts Chinese government intentions in the South China Sea. It shows that China does have some participation and involvement in the acknowledged international ports. But with the exemption of Sri Lanka's Hambantota and possibly Myanmar's Sittwe port, they are currently not used by China and there are currently no signs and intentions of the Chinese government to develop these ports in future for military purpose. Second, there is no doubt that china is interested and believe in constructing relationships with countries that are small but are strategically important, but for smaller countries to openly side with china means opposing other regional powers like India and United States. Such action by smaller countries will be considered awfully risky mediation. Now a day's the world is considered a global village. A country can severely affect its economy and diplomatic relation while choosing one great power over another. Because of less developed countries reliant on foreign trade, aid, and investment for development 
purpose in their countries. Third, the government and officials of the respective countries, who comes under the string of "pearl" web, have explicitly snub reports, which claimed that they have given china any privileged treatment and that Beijing is inaudible in building and/or planning to build military bases in their autonomous terrains (Tea, 2011).

\subsection{Conceptualizing "Economic Corridors"}

To achieve strategic growth and economic development the countries around the world, intelligent economies now focus on implementation of economic corridors strategies (fujita, 1999). On the whole, in order to improve a specific area in a mention time period, the economic experts argue that economic corridors can play its role and it is a venture of economic expansion aim at increasing economic growth and stability (Abednego, \& Ogunlana, 2006). Interestingly, no comprehensive and holistic definition observed in the academic literature. However, it the context of emerging trend in smart economies, it holds synergy, core resource sharing under the unified goal and objectives to create unique value to grow and survive while sharing common grounds. (Rogoff, 2003). Subsequently, from a theoretical inspection, Economic Corridors usually centered in urban settings tie financially viable agents along a pre-defined geographical locations and grant important connections amid economical focal points(Morrison, 2009).

More thoroughly, with in precise geographic locations the Economic corridors assemble the local trade and infrastructure, increase production and enhance economic growth because of the increase in business activities in pre-define areas results in widening the benefit to rural areas through infrastructure development and opening out of production activities(Malik, 2015). Hence, these economic strips are intended to craft comprehensive international value chain, connecting local economic nodes which creates a preferable and constructive business environment. To attain such benefit a corridor should be built and move ahead not simply helping local people and serving as a 'passage for the transit of goods and commodities' but It should have the ability to work as an 'industrial corridor' and 'develop a sound business hub, by providing viable road and railways infrastructure which is an important requirement to magnetize investments into export oriented industries and manufacturing" (Ruhl,Kraft \& Lant, 2013).

Pakistan and china claim and enjoy "all-weather" companionship. The two countries share a border at khunjrab pass in order to take opportunity of the share border and increase the economic growth, the two friendly countries in the year 1982 consummate the famous Karakorum Highway (KKH), connecting China's Kashgar to Pakistan's Islamabad, all the way through the Khunjerab Pass. To make the highway functional and feasible for all sorts of traffic throughout the year, the Karakorum High Way (KKH) was lengthened and restructured from time to time. Pakistan's Karachi and Gwadar ports in south are linked with Karakoram High Way (KKH) through network of roads (Irshad, 2015).

Figure 2: CPEC Investment Tree

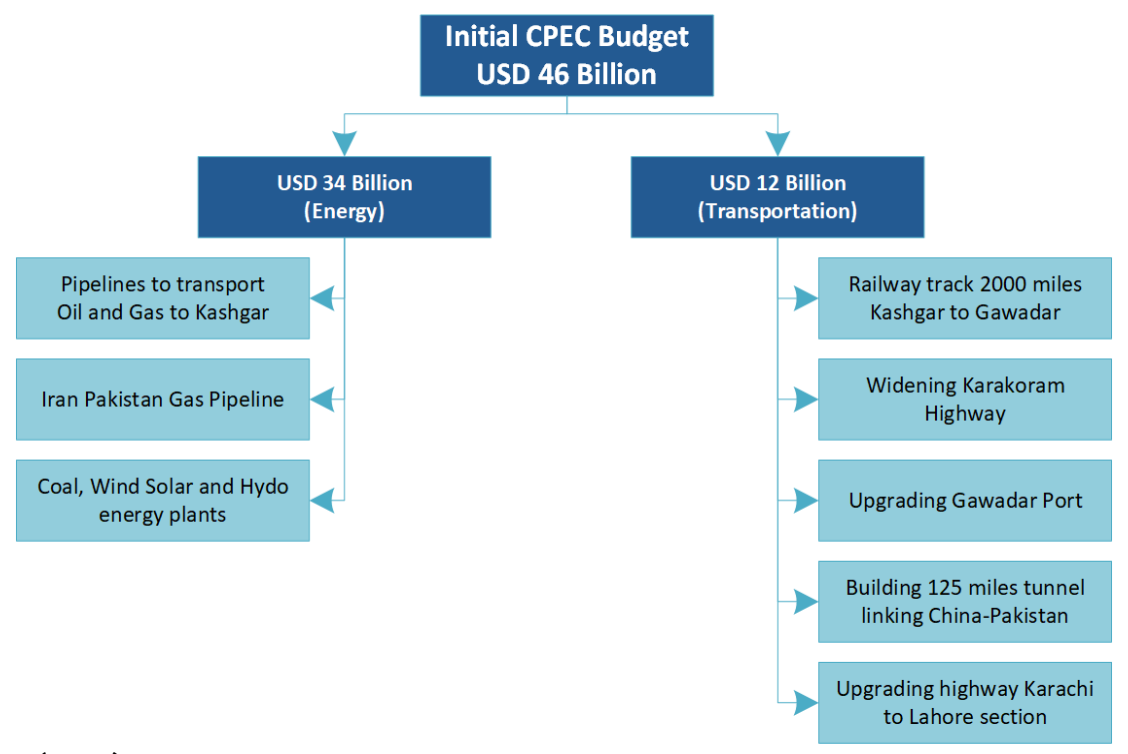

Source: Irshad, M. S. (2015) 
China has shown willingness and is committed to spend around $\$ 46$ billion for CPEC project and in other developmental deals. This is by far china's prime and biggest foreign direct investment (FDI) in Pakistan, which is equal to Pakistan's 20\% of annual GDP (Bhattacharjee, 2015). In total, some \$34 billion will be invested in energy sector to generate 17,000 megawatts of electricity. The remaining money will be used to upgrade the transport infrastructure, which includes the up gradation and installation of new railway lines between Peshawar the northwest city of Pakistan and port city of Karachi situated in south of Pakistan. (Shah, 2015).

China is taking keen interest in the development of Gwader port and Gwader region, because using Gwader port as economic and trade hub will give Beijing a direct,constant and long-term grip and dominance in the Indian Ocean which is contiguous to Persian Gulf, competently making china to enjoy supremacy and exercise their power in two-oceans. The aim of CPEC to work as a safe channel connecting three billion people in Europe, Asia and Africa. Which is also one of the most important projects comes under the umbrella of one Belt and one Road plan as well, the CPEC is intended to revitalize the original Silk Road with stress on communications, transportation and build the strategic structure of mutual collaboration. The project links China's approach to develop its western part with Pakistan's meditation on enhancing its economy, involving the creation of Gwadar Port, together with spotlight on energy collaboration and investment programs (Kaplan, 2011). In the meanwhile, the external response to this development is hard to determine, i.e. the strategic response of neighbouring countries like India and Iran.

The next section of the document will discuss the importance and the interest of each country in the CPEC and Gwadar port.

\subsection{Port: Gwadar Port}

On 8 September 1958, the small town of was acquired by Pakistan from Oman for $\$ 3$ million (Iqbal, 2015). But until 2002 no such major work or plan was carried out to functionalize the port. Pakistan requires sea ports for transport and also strong naval for ocean defence - because in past the conflicts with India, the Indian Navy many times swiftly barricade Karachi, which in result strictly restraining the Pakistan Navy's capabilities. Gwadar,a profound warm-water dock which is 470 Kilo Meter away from Karachi, look like an idyllic place for a new passage to the Indian Ocean. In 2006 in order to complete the first phase of the port, china grants $\$ 198$ million, At Pakistan's request. But china was unenthusiastic about further development. The developmental project consists of three stages, so Pakistan was still waiting for investment to complete the remaining two phases (Ali, 2013).

\subsubsection{Strategic importance of Gwadar}

According to the Bloomberg Business on April 1, 2015 "The move represents a shift toward greater economic cooperation between Pakistan and China, which have long had close security ties amid common disputes with neighbouring India. The corridor would give China access to the Indian Ocean and lead to investments that would help ease power shortages that are hindering economic growth in Pakistan. " (Mangi \& haider, 2015)

The completion of CPEC will swell different operational business routes between China, Africa, and the Gulf countries. To keep the Chinese economy vibrant, Beijing is concerned about Energy issues. As China is one of the world's largest oil importers. This corridor will give an opportunity to lay down oil pipelines through Pakistan. This in result would shorten ocean travel through Southeast Asia (Clark, 2014).

China devices to construct oil storeroom facilities and a processing plant at Gwadar Port and also at different zones along with the corridor, which will help to transport different goods and energy to its Xinjiang Uighur Autonomous Region without going through waterway of Malacca, the strait of Malacca is not secured one and can be blocked by the U.S. or India if the hostilities break out in the region (Chen, 2017).

The Asian Development Bank terms the project as "CPEC will connect economic agents along a defined geography. It will provide a connection between economic nodes or hubs, centred on urban landscapes, in which a large amount of economic resources and actors are concentrated. They link the supply and demand sides of markets". According to Chinese Foreign Ministry Spokesperson Hua Chunying, the corridor will "serve as a driver for connectivity between South Asia and East Asia." 
Mushahid Hussain, chairman of the Pakistan-China Institute, told China Daily that the economic corridor "will play a crucial role in the regional integration of the 'Greater South Asia', which includes China, Iran, Afghanistan, and stretches all the way to Myanmar." This project will have a positive effect and can play important role in the development in western China, where in past tensions in that region between the government and radical separatists were witnessed. To drive its economic growth CPEC is considered imperative to Pakistan to boost its economy. In 2015, the agency acknowledged that much of the project's key benefits would not materialize until 2017, but stated that it believes at least some of the benefits from the economic corridor would likely begin accruing even before its completion. A study by the Pew Research Centre in 2014 found that 78\% of Pakistanis have a positive view of China (News, 2015).

\subsubsection{China interest in Gwadar Port}

China has a great strategic interest in Gwadar. Following are the important ones: -

- China is relying deeply on the import of oil from the gulf countries; meanwhile, these oil imports and other trade products passes through very long route, under the American navy influence through the channel of Malacca. After reaching the Chinese East Cost, these import products have to be shifted to the west of china which is thousands of miles away from the east coast in the land. So the Chinese trade to the west of china through port and then Karakoram Highway $(\mathrm{KKH})$ it's much safer, cheaper and shorter route.

- Because of oil reservoirs and the current conflicts, in the Middle East the entire region has become a Flashpoint and volatile area in the world. The Government of Pakistan has previously devoted by providing a marine Base to China in Gwadar. This action will not only protect the but also take the two countries Friendship to new stature.

- Chinese export Goods will unearth an easier, shorter and protected route to the Middle East, which in result will increase profitability and growing trade.

- China will reap a great profit from the industrial districts by establishing industries close to the markets(Pant, 2012).

\subsubsection{India's concerns}

Regardless of such a vast capital building initiative by a contender in the area, the main point of strife for India is the China-Pakistan Economic Corridor -CPEC, which is also part of one belt one road strategy (OBOR) strategy. At the moment china enjoys and drives their influence on the port of Gwadar. Which is not far away from Pakistan old commercial port-The Karachi port; where the Gulf of Persia meets with the Arabian Sea? While the announcement of \$46 billion projects between Islamabad and Beijing, which also includes other developmental programs, in all provinces of Pakistan, including investments in Azad Kashmir. Such investment in areas which is close to the line of control (LOC) will make china and Pakistan strategic ties much stronger. But such developments are the point of concern for India.

The China-Pakistan Economic Corridor's consent comprises, that the investment will be not just limited to the development of port but energy infrastructure which includes making of new roads and rail lines and installation of fibber optics. This means that Pakistan will lose its influence in Gwadar, which is, in fact, becoming a de-facto Chinese Naval staging post in the Persian Gulf area.

In the near future with the emergence of new developmental projects between China and Pakistan could significantly fiddle Indian dominance in its own back yard- the so-called Indian Ocean region. In May 2015 the Indian External Affairs Minister SushmaSwaraj said that Prime Minister Narendra Modi, during his trip to China, had "very strongly" raised the issue of the China-Pakistan Economic Corridor going through Pakistan-occupied Kashmir (Azad Kashmir). This, along with China's rising influence in the Indian Ocean, remains the two main distress spots for New Delhi to give any sort of primacy to OBOR in its own foreign policy account.

For New Delhi, one belt one road (OBOR) may be a prospective financially viable opportunity but it also intimidates India's interests. India's ex- foreign secretary Shyam Saran recently wrote that if China indeed succeeded in the economic and geopolitical aims behind OBOR, India may get "consigned to the margins of both land and maritime Asia." (Kabir 2016). 


\subsubsection{Iran and India Investment in Chabahar port}

Pakistani Gwadar port is just seventy-two Kilometres away from Iranian Chabahar port. Chabahar is to be found in Sistan-o-Baluchistan a south-eastern province of Iran. After 9/11, India and Iran Naval collaboration has been observed in the Indian Ocean and as well as in the Arabian Sea. To enhance regional trade on 20th may 2015 India and Iran concluded a belated Chabahar port deal. In order to get access to central Asian countries along with landlocked Afghanistan Indian has taken a huge interest in the development of Chabahar port near the Iranian border. Both countries agreed to start up the developmental and up-gradation process of Chabahar port in 2003, but due to Iranian nuclear programs and United States, strict sanction on Iran slows down the developmental process.

Now as the situation gets better and the sanction which was imposed on Iran due to its nuclear program is eased up by the United States of America and P+5 countries, India got an opportunity to get benefit from the current situation. From Chabahar to Kandahar, India also has built a highway. To trade with Afghanistan India has utterly evaded Pakistan, which will connect India to Central Asian countries because central Asia and Russia has direct access to Afghanistan mineral assets. This corridor which not even evade Pakistan but also Taliban stronghold areas in Afghanistan that is why Iran and Afghanistan also take a huge deal of interest in making of this corridor (Afzal, 2015), India gives great importance to Chabahar port because it's the gateway to Central Asia for Indian goods and also directly investing in Afghanistan and establishing its self as a key stack holder.

While Pakistan limiting India by not giving direct entrance to Afghanistan through its territory, that's why this route and the port geographical locations plays a key role and increase its significance because of its placement in the Arabian sea. Once serviceable, analysts say that Chabahar will further destabilize or undermine the Gwadar. While Islamabad and Beijing both had soaring expectation from CPEC, but the mutiny in Pakistan province of Baluchistan and law order situation is proving to be a tough task for both the countries. After the complete withdrawal of international troops from Afghanistan, the Chabahar port will serve New Delhi a base to position its self in the Arabian Sea (Fatima \& Jamshed 2015). To start trade activities at Chabahar, and to seek sanctions waiver on Iran, India may like to start discussions with the United States of America. Once the Iran nuclear deal is completely sealed, India will spend $\$ 85 \mathrm{~m}$ on Chabahar port in order to obtain high-tech equipment and set up container terminal and a multi-purpose berth, whose total operation cost is estimated $\$ 22.95 \mathrm{~m}$ annually (Shah 2015).

In the development of Chabahar port both Iran and India have invested a considerable amount of money. In Iran's north- zahidan is directly linked with Chabahar through 600-kilometer road. While in 2009, in the south-western Nimroz province of Afghanistan India spent \$100 million on the construction of $220-\mathrm{km}$ Zaranj-Delaram road. Which is $700 \mathrm{~km}$ away from south-eastern Iran and can be easily extended to connect Chabahar. Iran has also an initiate to the construction of a railway line from Chabahar to Zahidan where it connects the Iranian rail network to Central Asia. Recently, Afghanistan also finalizes a (tripartite trade agreement) with Iran and India on using the Chabahar Port as substitute route (Ayaz 2015).

\subsection{Policy design and its impact on Pakistan's social, economic and political aspects}

Terrorism, intimidation and violence are directly linked with poverty (Sambanis2008) and the revelation of the OBOR anticipate that the regional countries and the world will get advantages from trade and will develop economically. Similarly, in the same context it will connect Pakistan's less developing areas with economic hubs though railways and roads bringing more jobs and developments, if the China-Pakistan Economic Corridor (CPEC) is urbanized appropriately. Due to the arrival and implementation of CPEC it will have a positive impact on Pakistan's less develop provinces such as Baluchistan and Khyber-Pakhtun-khwa and as well as china's Xingjian province will also obtain tremendous economic profit and stability .

\subsubsection{Security (Internal Threat)}

One of the most serious and major challenges faces CPEC is the security issue. Different militant groups stretch from to Chinese province (Xinjiang), these groups have different names such as Baluchistan Liberation Army (BLA), East Turkistan Islamic Movement (ETIM), Tehreek-e-Taliban Pakistan (TTP) and political parties having militant wings (Abid, \& Ashfaq, 2015). These militant groups don't 
have any direct enmity with china, but in order to destabilize Pakistan, they will try to attack such Chinese sponsored projects, which can be beneficial for Pakistan (Kilcullen, 2011).

There are many hurdles towards the successful implementation of CPEC, but on the ground CPEC is facing are two main hindrances: First, The strife situation in the province of Baluchistan and as well as the insurgency issue from global Islamist terrorists. But in reality the current fragile situation in Baluchistan regarding insurgency should be considered one of the top challenges for successful competition of CPEC project, because Gwadar port is the part of Baluchistan province and any security situation in Baluchistan will affect the successful operation of Gwadar port (Kronstadt 2009).

In this scenario, it is essential to highlight Baluch people's relationship with Pakistan's federal government, which was not normal right from the beginning. The people of Baluchistan from the beginning they were economically oppressed and politically marginalized, in the past against the federal government some tribes in Baluchistan were involved in quite a few armed uprisings. One of the main reasons for such uprising against the federal government was unjustified distribution of natural resources and wealth as the matter of fact Baluchistan is having abundance of natural reservoirs. Above all Baluchistan has best strategic location. But still the province of Baluchistan is the country's least urbanized and least mechanized region having the income and literacy rate at lowest level as compared to the other provinces. More than $50 \%$ of its inhabitants are living under the poverty line. In such situation, the Baluch rebel groups are of the view that CPEC is a foreign occupation of their native land and on natural resources, and such occupation will further dissolve the identity of native Baluchi's on the name of economic expansion. In addition, the Baluch nationalists see this Economic Corridor as Punjabi expansionism and a policy by the federal government to make stronger its grip on Baluch's wealth and natural resources (Wolf, 2016)

Inside China, Xinjiang province which is Muslim Uyghur population area was hit by violence, and ethnic tensions in the past, because of low development and poverty in the area, it is considered as the spongy belly of china. The militant group ETIM was held responsible that give rise to such extremist tensions in Xinjiang province (Newton, 2016). Chinese considered ETIM is the conjunction of three evils extremism, separatism, and terrorism. Militant groups are found in abduction and execution of Chinese workers in different projects in Pakistan (Tschantret, 2016).

But keenest opponents and the trouble maker for Chinese investment in Pakistan are the Baloch nationalist separatists. Three Chinese engineers were killed in 2006, which were claimed by BLA (Baluchistan liberation army) in the hub, a town west of Karachi. In Turbat, just a week before the Chinese president's visit to Pakistan, at least 20 Pakistani labourers were killed in cold blood by BLF gunmen. Separatists also usually attack government machinery, power hubs and transmission lines asides from other acts of terrorism in the interior Baluchistan (Falak 2015).

In the existing pool of literature, which discusses the impact of internal security in the country, also defines the security as a strong predictor of economic growth and inward foreign direct investment (Ramasamy \& Yeung. 2010). To give the quick view about the economic stability as a challenge for Pakistan, the sect section will discuss the current economic situation of the country.

\subsubsection{Economy (Emerging Challenge)}

If the efforts for completing CPEC and its design is doesn't halt by any internal or external forces. Then there is a good chance to avail the broader visualization of OBOR that is the linkage of CPEC with Central Asian Corridor. Which will steer the Foreign Direct Investment (FDI) in Pakistan which almost stopped from several years due to ongoing war against terrorism in the country? The economic boost due to the foreign direct investment (FDI) in the less volatile region will get new life to those whose businesses and economic activities already dried up because of terrorism. It will created more opportunities and develops new jobs and business activities. In the world stock market Pakistan's stock exchange was ranked among top ten market performers due to the assurance of china's the $\$ 46$ billion investment (Ibrar et al, 2016) and in June 2015 Moody's raises credit ratings of Pakistan, for the first time after 2008 - these are all positive and good signs of economic growth for Pakistan (Jeanette 2015). These aspects and economic dimension have led Pakistan to achieve high mark in economic trend. David M. Darst has stated, "rise of Pakistan is just a matter of time." In theory, the curse of terrorism is bound to be eliminated if the project is successfully executed in every aspect by the support of local population (Hal, Shukui \& Iqbal, 2015) 
Pakistan emerges on world map in August1947, at that time having population of 3omillion people and their capita per income stands at $\$ 100$. Due to the weak GDP participation of manufacturing industries in the country's development, the Agricultural sector was consider back bone and contributing 50\% to the total economy(Kauppert, 2014)These days In terms of Purchasing Power Party (PPP) Pakistan economy currently ranked $26^{\text {th }}$ established economy in the world.

Figure 3: GDP growth rate of Pakistan

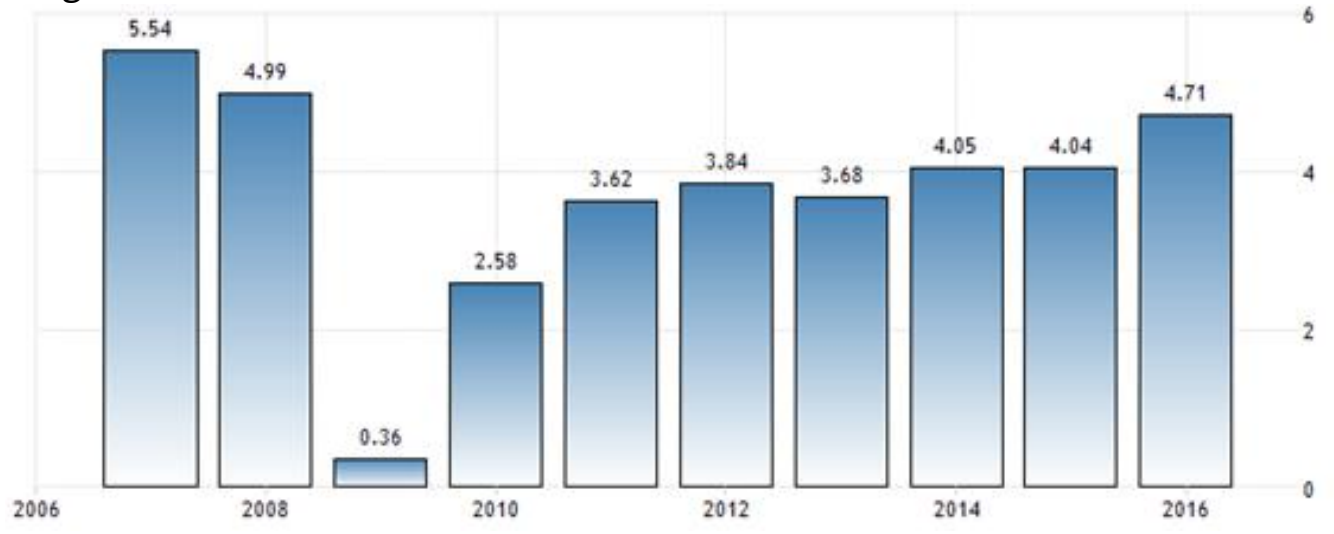

Source: Trading economics, 2017.

According to the statistics for the Fiscal Year 2015 release by IMF the contemporary GDP of Pakistan stands at USD 271 Billion. The current GDP value of Pakistan corresponds to $0.39 \%$ to the total economy of the world. The Gross Domestic Product (GDP) in Pakistan lingering to $4.71 \%$ in the year 2016 as compared to the preceding year. From 1952 until 2016 Pakistan GDP Growth Rate averaged 4.91\%. Getting all time soaring height of $10.22 \%$ in 1954 and record stumpy level of $-1.80 \%$ in 1952 (Trading Economices, 2017).

According to world meter population info 2017 the current data reveals that total population of Pakistan is 196 million having yearly change in population is $2.03 \%$ which equals to $2.62 \%$ of total world population. Pakistan also ranked $6^{\text {th }}$ largest in the world in terms of most populace country in the world(Worldometers, 2017).Pakistan is also blessed with natural possessions such as minerals, widespread natural gas reserves, gasoline, petroleum, limestone, copper and iron. Pakistan is an agricultural based country and her main crop includes Rice, Sugarcane, Wheat and most importantly Cotton.

Total farming land is $35.2 \%$ and the land which can be used for growing crops is $27.6 \%$.(CIA, 2017). Pakistan economy is considered as emerging economy in the developing world. It has prospective to turn out to be one of the world's prevalent economies in the $21^{\text {st }}$ century(Tavia Grant, 2011).

Major sell overseas of Pakistan include fabric, fleece good, sports, chemical substance and carpet. The biggest city of Pakistan is Kara-chi, which is the main economic hub of Pakistan. Through the secondary source of fact book by CIA, the total USD of 29.87 billion exported by Pakistan in the year 2013-14 and gained the value benefit of USD 5.741 billion through service sector.(Trading Economices, 2017)

Table 1: Main exporting partners (CIA World fact book, 2016)

\begin{tabular}{lr}
\hline Country & Percentage of total exports \\
\hline US & $13.3 \%$ \\
China & $10.9 \%$ \\
UAE & $8.6 \%$ \\
Afghanistan & $8.5 \%$ \\
Germany & $5.1 \%$ \\
\hline
\end{tabular}

According to world fact book, in 2013-14 total import of Pakistan is $\$ 41.668$ billion. Major import partners include countries listed in the table. (CIA World fact book, 2016) 
Table 2: Main importing partners (CIA World fact book, 2016)

Country Percentage of total imports

\section{China}

Challenges: The US invasion of Afghanistan in 2001, not only increased the flow of refugees to Pakistan, but that huge influx also has given rise to terrorism across the country. Due to terrorist activities, the developmental projects were abandoned, which severally affect the overall economic growth rate. Regarding economic and security issues Pakistan persist in paying a heavy price, in order to obtain law and order situation and eliminate terrorism a significant portion of national resources both human resource and material, have been diverted to address the emerging security challenges.

Due to instability in Afghanistan, the extremism and increase in terrorism not only damage Pakistan economy, but the prevailing situation is also responsible for the suffering of innocent human lives because of the indiscriminate attacks against the civilian population. This chaotic situation upset Pakistan's customary trading and economic activities and significant delays around the globe, which results in higher costs of production and also created commotion in the production cycles. Because of this uncertainty, Pakistani products have steadily lost their market share to their opponent. As a result, Pakistan economy could not pick up the pace as it was intended. The foreign Investment outflow and negative trends of outsourcing of resources in Pakistan has further worsened the situation (Survey 2014-2015).In order to assess the impact of the incidents of terrorism on the economy of Pakistan during the past several years, the estimates for FY15 has been prepared in consultation with all relevant Ministries / Departments / Provincial Governments / Autonomous bodies etc. Summary of year wise losses is presented in Table -3.

Table 3: Summary of losses due to terrorist attacks

\begin{tabular}{|c|c|c|c|c|}
\hline \multirow[t]{2}{*}{ S. No } & \multirow[t]{2}{*}{ Organization } & \multicolumn{2}{|r|}{ Years } & \multirow[t]{2}{*}{ Total } \\
\hline & & $2013-14$ & $2014-15^{*}$ & \\
\hline 1. & Exports & 0.53 & 0.73 & 1.26 \\
\hline 2. & Compensation to Affecters & 0.04 & 0.01 & 0.05 \\
\hline 3. & Physical Infrastructure & 0.42 & 0.50 & 0.92 \\
\hline 4. & Foreign Investment & 2.01 & 0.09 & 2.10 \\
\hline 5. & Privatization & 0.00 & 0.00 & 0.00 \\
\hline 6. & Industrial Output & 0.03 & 0.02 & 0.05 \\
\hline 7. & Tax Collection & 2.52 & 2.00 & 4.52 \\
\hline 8. & Cost of Uncertainty & 0.07 & 0.002 & 0.07 \\
\hline 9. & Expenditure Over run & 0.29 & 0.62 & 0.91 \\
\hline 10. & Others & 0.72 & 0.55 & 1.27 \\
\hline \multicolumn{2}{|c|}{ Total Losses } & 6.63 & 4.53 & 11.16 \\
\hline
\end{tabular}

*: Estimated on the basis of 9 months' actual data (July-March). Source: M/o Finance, M/o Interior, M/o Foreign Affairs, Joint Ministerial Group

Since 2001 for almost 14 years, Pakistan face terrorism issue due to which direct and indirect cost incurred by Pakistan is said to be US\$ 106.98 billion which is equivalent to Rs. 8,702.75 billion. Details are given in table 4.

According to Pakistan's Minister for Planning Development and Reform Ahsan Iqbal, "PakistanChina Economic Corridor is not the name of a single route or alignment, it is a comprehensive package of cooperative initiatives and projects encompassing regional connectivity, information network infrastructure, energy cooperation, industry and industrial parks, agricultural development, and poverty alleviation, financial cooperation as well as livelihood improvement including municipal infrastructure, education, public health and people-to-people communication which will result in thousands of new ventures and millions of jobs in every part of Pakistan" (Ahmar, 2015). 
Table 4: Estimated losses (2001-2015)

\begin{tabular}{lrrr}
\hline Years & \$ Billion & Rs. Billion & \% Change \\
\hline $2001-02$ & 2.67 & 163.90 & - \\
$2002-03$ & 2.75 & 160.80 & 3.0 \\
$2003-04$ & 2.93 & 168.80 & 6.7 \\
$2004-05$ & 3.41 & 202.40 & 16.3 \\
$2005-06$ & 3.99 & 238.60 & 16.9 \\
$2006-07$ & 4.67 & 283.20 & 17.2 \\
$2007-08$ & 6.94 & 434.10 & 48.6 \\
$2008-09$ & 9.18 & 720.60 & 32.3 \\
$2009-10$ & 13.56 & 1136.40 & 47.7 \\
$2010-11$ & 23.77 & 2037.33 & 75.3 \\
$2011-12$ & 11.98 & 1052.77 & -49.6 \\
$2012-13$ & 9.97 & 964.24 & -16.8 \\
$2013-14$ & 6.63 & 681.68 & -33.5 \\
$2014-15 *$ & 4.53 & 457.93 & -31.7 \\
Total & 106.98 & 8702.75 & \\
\hline
\end{tabular}

Estimated on the basis of 9 months actual data Source: MoF, M/o Interior, M/o Foreign Affairs Joint Ministerial Group

According to the views of Asian Development Bank regarding the project, which state as, "CPEC will connect economic agents along a defined geography. It will provide the connection between economic nodes or hubs, centred on urban landscapes, in which a large amount of economic resources and actors are concentrated. They link the supply and demand sides of the market (Ahmar 2015). Currently, in South Asia the second largest trading partner of China is Pakistan; the total trade volume between two countries reaches up to the US $\$ 19$ billion (Greenaway, Mahabir et al. 2008).According to statistics affirmed by the State Bank of Pakistan, during July-March 2015/16 the Foreign Direct Investment -FDI which the country received is US \$975.4 million as compared to the US $\$ 832.2$ million in the previous fiscal year. The FDI from China grows up by $167 \%$ to the US $\$ 516$ million during JulyMarch 2015/16 as compared to the US $\$ 193.3$ million in the consequent period of the previous fiscal year (Akhter 2016). The backward and remote areas will develop as the CPEC would pass and touches all the four provinces and as well as Gilgit-Baltistan and Azad Kashmir.

The biggest and poorest region but rich in minerals the province of Baluchistan will benefit most and ultimately benefit the economy of Pakistan, once these hidden treasures comes onto the surface. Baluchistan has the world largest reservoirs which include (projected stock of 200 million tons of iron and 217 million tons of coal, Saindak gold and copper mines contain treasury up to 412 million tons of copper and gold, RekoDik 5.9 billion tons of copper and gold) (Ahmad 2015). While analyzing different industrial sectors, which can contribute to the economy, one cannot sideline the mining sector. Because of CPEC Pakistan mining, the sector would flourish. It would give away to trim down towards the unemployment in local areas; it will build up micro, middle and undersized industries, thus, promoting and giving benefit to the local population. Pakistan Federal Minister for Planning Development and Reforms, Ahsan Iqbal said: "The production of 10,000 megawatts of energy under the CPEC would help overcome the energy crisis by 2018 as well as upgrade the existing road network of the country" (Iqbal 2016).

Higher Education institutions and colleges are also part of the plan, which will be built on CPEC's Western route. These Higher Education institutions will transform the people of underdeveloped areas. The Education will empower the people of FATA, Zhob, and Gwadar. Because of terrorism Pakistan Tourism industry has been badly hit, because of that Pakistan not only got a significant decrease in their economy, but also the people who were living in those areas where their lively hood based on tourism .the completion of CPEC can break through for Pakistan tourism industry and it will soon flourish under CPEC (iqbal 2016).It can be concluded from the above literature, that the economic stability needs the internal institutions to be strong and stable to assure and gain the trust of the 
foreign investors and the ongoing economic development. To address the political instability related factors important in the context of CPEC, the next section will briefly explain the political situation and the possible critical factors to explain future challenges for the country.

\subsubsection{Political Instability}

Multi-billion dollars' project around the world may face hindrance because of political instability and CPEC can't be safeguarded from such situation. Chinese President Xi Jinping's visit to Islamabad in September 2014 was called off due to political party's sit-ins in the capital. Later on, the issues were solved between the government and the Political parties while both agreeing on making of the judicial commission to solve the rigging issue an allegation made by Pakistan TehreekInsaf Party (PTI). Pakistan's emerging second largest party led by Imran khan (PTI) has played a positive role in calling for national support for the CPEC, but the danger still has not eroded. All the political parties refrained from such actions that could endanger such national level project.

In recent times some nationalist parties in Khyber Pakhtun-Khwa and Baluchistan shows there concern over the routes, their concern is that these routes only favours the eastern provinces and deprives the west province of the development. Due to these allegations, which have no fact on the ground, still, Chinese and Pakistan government tried to alleviate these concerns and fears by directly interacting with these nationalist parties? The governments also took some good steps and initiate open public debates on media in order to engage every stack holder and stop the public to create such confusion which can halt or harm the work on CPEC.

Meanwhile, on the international front, there are also some political challenges. India is not happy with the construction of CPEC part in Gilgit-Baltistan, and they are using diplomatic channels to stop the construction in Gilgit-Baltistan region because India thinks it is disputed territory and consider it to be a fundamental part of its country. The United States Of America (USA) also shows their concerns and anxious about china presence in the India ocean and its direct access to the region. It has been reported many times that the United States Of America (USA) tried to deter Pakistan not to allow or help china in such development and at one time the United States Of America (USA) try to persuade the government of Pakistan that only suitable operator for port is Singapore (Falak 2015).

The 18th constitutional Amendment in the constitution of Pakistan, a lot of command and supremacy has been designated to the provinces. This constitutional change has made it difficult to build consensus on such national issues and multi-billion dollars project such as CPEC. In general, the inconsistent and unstable political system in Pakistan may hinder the achievement of CPEC. While the government of Pakistan has signed historical and frequent (MoUs) with Beijing and other states; the question is how many of them have been (or will be) finished or achieved on time is still to be seen (Ali 2015).

In the context of the novelty of the current document, on the basis of the current socio-political, strategic perspective, through the prism of existing literature and populated media related content about Pakistan. The current study concludes the internal security, political system and shaky economy are the most critical success factors to drive the future of CPEC, Pak-China smart power and strategic alliance of the span of next two decades. Furthermore, the recommendations and mentioned at the end which precisely highlighting suggested future actions for the country's strategic decision makers.

\section{4. $\quad$ Predictable strategic directions as findings}

As per the discussed facts and figures in the current strategic scenario, a few of the predictions and the critical observations are the following

- CPEC is considered and described by the leadership of both countries (China-Pakistan) as a game changer for the region. Though, the benefit of CPEC will become conscious over a period of 10-15 years. In order to achieve these benefits, it requires constant and continued efforts from the both countries leaderships to stay firm on the track.

- In order to meet the deadlines and achieved the specified objectives, it is necessary and to make sure that all the Memorandums of Understandings (MoUs) and any new policy agreement regarding CPEC between two countries in future should implement and put into action without any hindrance. 
- At the same time, different projects are running under the umbrella of CPEC. In order to improve the performance and maintain the quality of these different projects, it requires a firm inspection team to safeguard these projects against the corruption and kickbacks. In April 2015, the formation of Prime Minister's Delivery Unit (PMDU) to keep an eye on the execution of the projects under the CPEC is an encouraging move.

- People working on this corridor, one of the major concerns is to provide Safety and security to these people. Engineers, labours and technicians and other working staff from china, Pakistan must take some safety measures and to ensure fool-proof security to Chinese personnel.

- Pakistan's geographic location is considered a gateway to the Central Asian republics; the successful completion of CPEC will make Pakistan a business hub and will open business routes to the countries like Burma, Bangladesh, and Indonesia. So in this regard, Pakistan business community, and private sector societies need to come forward and play a positive role in making CPEC a success.

- Pakistan is facing energy crisis from the last 10years, it's a great opportunity for Pakistan to fully utilize this project because the completion of CPEC will play a major role in easing the energy crisis in Pakistan. CPEC will connect the country's economy on three sides with its neighbours, the North, East and West sides.

- Some extremist and racial elements, which are declared as Anti- State elements could dent the creation of CPEC. And those who oppose the construction of this corridor can misguide the people living in Gilgit-Baltistan, Baluchistan, and Khyber Pakhtun-Khwa to oppose this corridor. The East Turkistan Islamic Movement (ETIM) in Xinjiang may also craft some problems. So to counter these annoyed elements the government of both countries should utilize a multi-dimensional approach to averting the hidden despicable agendas of these anti-state elements. This will enable to encircle both soft and hard power.

- A Pakistan-China integrated counteract terrorism mechanism is vital to tackle such issues. Besides that, the active role of media and students educational exchange programs can also play a positive part to eliminate the pessimistic observation and dread over the CPEC project.

\section{Conclusion}

This paper has highlighted the benefits and issues concerned with CPEC, which is thought to be the part of china's String of Pearls strategy. Most of the observers are of the believe that this project could be a game changer in south Asia. The economic corridor starting from a deep-sea port in Pakistan at the Indian Ocean will connect the land lock province of china's Kashgar region. It will not only shorten the trade route for china import and export, but china will also establish their naval dominance in the Indian Ocean. With the completion of this project, Pakistan will also get direct access to Central Asian Republics. Some countries have shown their concern over Chinese involvement in such projects. The Central Asian Republics getting direct access to the Indian Ocean through may challenge Russia's Monopoly and its influence in Central Asian Republics. Meanwhile, Russia enjoys control over the accessible means starting from Caspian and ends in Europe and beyond. Due to the creation of new routes and economic pipelines in terms of the CPEC and interrelated economic passageways may confront Russia's domination. India is another country which has openly declared and shows their concerns over this corridor. India believes that this corridor passes through disputed territories and restrains china from such projects. By putting Chinese in control of Gawadar port means Chinese Naval will be present in the Indian Ocean, from which India seems threatened. Because the project will create china's Sea Lines of Communication (SLOC), encircling India all way round from mainland China to Pakistan passing through Myanmar, Bangladesh and Sri Lanka.

Meanwhile, India is also finding ways to enter to Central Asian Republics through Iran. India's investment in Iran's Chabahar port is the part of Indian strategy to establish a naval base at the Arabian Sea and also get access to Central Asian Republic States. Because Pakistan denies India giving most favourable nation status, and do not allow India to trade directly with Afghanistan through Pakistan. But Pakistan has nothing to fear of Indian investment in Chabahar. Because the road from ZaranjDelaram towards Kandahar passes through Taliban's territory and Kandahar is said to be stronghold or birthplace of Taliban. The goods driven from Chabahar port all the way up to Herat, this by no means is a safe route for trade and it will make transportation exponentially costlier. The truth is that Kandahar 
is just few 100 miles away from Pakistan's (Chamman) border check post and Kabul just 200 miles from Pakistan's ancient and historical (Torkham) check post. So the goods passing through these areas will always be cheaper than Indian goods passing through Iran. India investment in Chabahar port can be used as a bargaining chip just to convince or pressurize Pakistan to allow India to trade with Afghanistan directly across its territory. The biggest concern for CPEC is the demand for intelligibility and transparency among the four provinces in Pakistan. After Baluchistan, the Khyber Pakhtun-khwa Government has express serious concern over corridor and threatens to halt the project in their part of the territory, if their demands were not meant.

Their demands include establishing of trade zones, share in energy projects and details of budgetary allocations. Because these two provinces leaderships are of the believe that Punjab is getting all the benefits and appears to be the front-runner and they consider it as China-Punjab economic Corridor. So in order to make this project successful, the federal government must work hard to eliminate these province grievances and must take bold steps to make things transparent, which will help in the successful completion of this project.

However, the current geopolitical scenario predicts that Game of Chess will be played on the 'Indian Ocean \& Eurasian Landmass'. The two foremost coalitions of countries, to be precise the 'Pivot on Asia' coalition lead by the United States of America (USA) and the 'One Belt One Road' coalition led by China will be playing on this land and sea based chessboard. The End game is that which group will 'Checkmate' the opponent on the mainly desirable piece of 'Heartland' also called the Central Asia. 'One Belt-One Road' central character that China has already 'captured' Gwadar \& Karachi Ports. The only query is how and what 'Pivot on Asia' will do to pursue Iran to have an entrance to Chabahar and Bandar Abbas port?

In the sum up, CPEC may have good and positive impact so far but its ultimate success depends on how much it has the capacity and ability towards regionalization and how much it can enhance its regional connectivity as much as possible. For that reason, it is important that CPEC should be incorporated and must be indulge with networks of roads, trade hubs, and energy sectors beyond China-Pakistan nexus. While connecting Gwader with Kashgar through CPEC both areas exclusively will be considered as special economic zone, such connectivity of roads will link Europe across Central Asian states and Russia. Nevertheless, if this project get success it is vital for Pakistan to open CPEC to its neighbours and allow them to participate in it. Such policy will bring more benefit to Pakistan and to the region. Pakistan should revise its regional policy and give up the policy of "strategic depth" and should unlock the CPEC to the countries in West (Iran and Afghanistan) and to the arch rival (India) in East; only then one can determine the CPEC major influence on regional connectivity and can become a game changer for regional collaboration in South Asia.

The CPEC can become a game changer for China and Pakistan and also for Central Asian Republics. That is why its success is essential and critical for national and regional significance, at the least. It is the utmost responsibility of the current government of Pakistan to act and perform beyond political constraint and address the internal disputes among the provinces and be cautious to external involvement. There is no grain of doubt, in our view, about China's persistent commitment in this respect.

\section{References}

Abednego, M. P., \& Ogunlana, S. O. (2006). Good project governance for proper risk allocation in public-private partnerships in Indonesia. International Journal of Project Management, 24(7), 622634.

Abid, M., \& Ashfaq, A. (2015). CPEC: Challenges and opportunities for Pakistan. Journal of Pakistan Vision, 16(2), 142-169.

Afzal, S. (2015). " port versus Chahbhar port." Retrieved May,25, 2015, from http://foreignpolicynews.org/2015/05/25/-port-versus-chahbhar-port/.

Ahmad, D. A. (2015). "“: Potentials and Prospects"." Retrieved January,28, 2016, from http://www.picss.net/-potential-and-prospects/.

Ahmar, D. M. (2015). ", "Strategic Meaning of the China-Pakistan Economic Corridor", ." Institute of Strategic Studies Islamabad2014 and 2015(December): 39.

Akhter, S. (2016). "FDI up 15Pc on CPEC Inflows in July-March”. The News. Karachi. 
Ali, E. H. a. G. (2015). The CPEC opportunities and challanges. . Daily Times. Pakistan.

Ali, G. (2013). China's strategic interests in Pakistan's port at . East Asia Forum.

Anholt, S. (2016). Places: Identity, image and reputation. Springer.

Ayaz, A. (2015). vs Chabahar. . The News international. Karachi-Pakistan, Jang Group of Newspapers.

Bhattacharjee, D. (2015). China Pakistan Economic Corridor.

Chen,A. (2017).Rebuilt port heralds success. The Telegraph .Retrieved May 6,2017,from http://www.telegraph.co.uk/news/world/china-watch/business/china-rebuilds-port-in-pakistan/

Chowdhary, M. (2015). China's Billion-Dollar Gateway To The Subcontinent: Pakistan May Be Opening A Door It Cannot Close. . Forbes. Usa, Forbes.com.

Christ, N., \& Ferrantino, M. J. (2011). Land transport for export: The effects of cost, time, and uncertainty in sub-Saharan Africa. World Development, 39(10), 1749-1759.

CIA. (2017). The World Factbook - Central Intelligence Agency. Retrieved July 18, 2017, from https://www.cia.gov/library/publications/the-world-factbook/geos/pk.html

Clark, G. (2014). The making of a world city: London 1991 to 2021. John Wiley \& Sons.

Dent, C. M. (2016). East Asian Regionalism. Routledge.

Falak, J. (2015). "CPEC internal significance and challanges." Retrieved june 30, 2015, from http://www.stratagem.pk/strategic-pulse/cpec-internal-signfigance-and-challenges/.

Fatima, Q. and A. Jamshed (2015). "The Political and Economic Significance of Indian Ocean: An Analysis." South Asian Studies30(2): 73-89.

Fujita, M., Krugman, P. R., Venables, A. J., \& Fujita, M. (1999). The spatial economy: cities, regions and international trade (Vol. 213). Cambridge, MA: MIT press.

Greenaway, D., A. Mahabir and C. Milner (2008). "Has China displaced other Asian countries' exports?" China Economic Review19(2): 152-169.

Hali, S. M., Shukui, T., \& Iqbal, S. (2015). One Belt and One Road: Impact on China-Pakistan Economic Corridor. Strategic Studies, 34(4), 147-164.

Holmes, J. R. and T. Yoshihara (2008). "China's naval ambitions in the Indian Ocean." The Journal of Strategic Studies31(3): 367-394.

Ibrar, M., MI, J., Rafiq, M., \& Karn, A. L. (2016). The China-Pakistan Economic Corridor: Security Challenges. DEStech Transactions on Economics and Management, (apme).

Iqbal, A. (2016). 3 varsities at CPEC route to start functioning soon. Pakistan Observer. Islamabad.

Iqbal, A. (2016). First phase of CPEC to be completed by 2018. The Nation. Lahore.

Iqbal, K. (2015). " Port: Harbinger of prosperity for Baloch people." Defence Journal19(5): 58.

Irshad, M. S. (2015). One Belt and One Road: Dose China-Pakistan Economic Corridor Benefit for Pakistan's Economy?.

Jeanette Rodrigues, "Moody"s Upgrades Pakistan Rating as Sharif Improves Finances," Bloomberg Business (New York), June 12, 2015. At http://www.bloomberg.com/news/articles/2015-0612/moody-s-upgrades-pakistan-rating-as-sharif-improves-finances

Jinchen, T. (2016). 'One Belt and One Road': Connecting China and the world. Global Infrastructure Initiative website.

Kabir, T. (2016). "Why India is worried about China's ambitious One Belt One Road initiative." Retrieved April,2, 2016, from http://cpecnews.com/why-india-is-worried-about-chinas-ambitiousone-belt-one-road-initiative/.

Kaplan, R. D. (2011). Monsoon: the Indian Ocean and the future of American power. Random House Incorporated.

Kauppert, P. (2014). ECONOMY OF TOMORROW: Case Study of Pakistan. Islamabad. Retrieved from www.fes-pakistan.org

Kilcullen, D. (2011). The accidental guerrilla: Fighting small wars in the midst of a big one. Oxford University Press.

Kostecka, D. J. (2011). "Places and bases: The Chinese navy's emerging support network in the Indian Ocean." Naval War College Review64(1): 59.

Kurian, N. (2014). India-China Borderlands: Conversations Beyond the Centre. New Delhi, SAGE Publications India.

Kronstadt, K. A. (2009, February). Pakistan-US relations. Library of Congress Washington Dc Congressional Research Service. 
Malhotra, N. K., \& Birks, D. F. (2007). Marketing research : an applied approach. Harlow : Prentice Hall: Financial Times, 2007.

Malik, A. A. (2015). Exploring the Dynamics of Urban Development with Agent-Based Modeling: The Case of Pakistani Cities (Doctoral dissertation, George Mason University).

Mangi, F., \& Haider, K. (2015). China superhighway to run through Pakistan-occupied Kashmir. Retrieved August 24, 2017, from http://www.livemint.com/Politics/1BSPn5G8USunbmlbVO9Vdl/Chinasuperhighway-to-run-through-Pakistanoccupied-Kashmir.html

Marantidou, V. (2014). "Revisiting China's 'String of Pearls' Strategy: Places 'with Chinese Characteristics' and their Security Implications." Pacific Forum CSIS Issues \& Insights14.

Morrison, M. (2009). Leadership and learning: Matters of social justice. IAP.

News, C. (2015). "China-Pakistan Economic Corridor." Retrieved January,5,2016, 2016, from http://cpecnews.com/china-pakistan-economic-corridor/.

Newton, J. (2016). The Oldest Foods on Earth: A History of Australian Native Foods with Recipes. NewSouth.

Niazi, T. (2005). ": China's Naval Outpost on the Indian Ocean'. Association for Asian Research. 28 February." The JamesTown Foundation5(4).

Pant, H. V. (2012). China's rising global profile: the great power tradition, Sussex Academic Press.

Pant, H. V. (2012). "The Pakistan Thorn in China-India-US Relations." The Washington Quarterly35(1): 83-95.

Prasad, R. V. S. (2009). The string of pearls. The Indian Express. New Dehli,India.

Ramasamy, B., \& Yeung, M. (2010). The determinants of foreign direct investment in services. The World Economy, 33(4), 573-596.

Ritzinger, L. (2015). "The china-Pakistan Economic Corridor Regional Dynamics and china;s Geopolitical Ambitions." The National Bureau of Asian Research. Strategic Asia, 2015-16.

Robson, C. (2002). Real world research: a resource for social scientists and practitioner-researchers. Oxford UK ; Madden Mass.: Blackwell Publishers.

Rogoff, B. (2003). The cultural nature of human development. Oxford University Press.

Ruhl, J. B., Kraft, S. E., \& Lant, C. L. (2013). The law and policy of ecosystem services. Island Press.

Saeed Shah, "China"s Xi Jinping Launches Investment Deal in Pakistan", The Wall Street Journal, 20 April 2015,

Sambanis, N. (2008). Terrorism and civil war. Terrorism, economic development, and political openness, 174-206.

Saunders, M., Lewis, P., \& Thornhill, A. (2009). Research methods for business students (5th ed.). Essex: FT Prentice Hall.

Shah, A. H. (2007-09). The volatile situation of Balochistan - options to bring it into streamline. Master Of Science In Information Operations Descriptive.

Shah, S. M. A. (2015). Chabahar vs . Dawn. Pakistan, Pakistan Herald Publications.

Survey, P. E. (2014-2015). "Impact of War in Afghanistan and Ensuing Terrorism on Pakistan'sEconomy."RetrievedJanuary,5,2016, from

http://www.finance.gov.pk/survey/chapters_15/Annex_IV_War_on_Terror.pdf.

Tavia Grant. (2011). On 10th birthday, BRICs poised for more growth - The Globe and Mail. Retrieved from https://www.theglobeandmail.com/report-on-business/economy/economy-lab/on-10 ${ }^{\text {th }}$ birth day -brics-poised-for-more-growth/article536100/

Tea, B. (2011). "Unstring china strategic pearls."

Trading Economices. (2017). Pakistan GDP | 1960-2017 | Data | Chart | Calendar | Forecast | News. Retrieved July 18, 2017, from https://tradingeconomics.com/pakistan/gdp

Tschantret, J. (2016). Repression, opportunity, and innovation: The evolution of terrorism in Xinjiang, China. Terrorism and Political Violence, 1-20.

Wolf, S. O. (2016). The China-Pakistan Economic Corridor: An Assessment of its Feasibility and Impact on Regional Cooperation.

Yogesh (2013). Security and Strategic Implications of the So-cWorldometers. (2017). Pakistan Population (2017) - Worldometers. Retrieved July 18, 2017, from http://www.worldometers.info/worldpopulation/pakistan-population/ 